\title{
Determination of dioxin-like polychlorinated biphenyls in soil and moss from Fildes Peninsula, Antarctica
}

\author{
WANG Qiang ${ }^{1,2}$, SHI YeHong ${ }^{1}$, HU JianXin $^{1 *}$, YAO ZiWei $^{2}$, FANG XueKun $^{1} \&$ DONG YiAn ${ }^{1}$ \\ ${ }^{1}$ State Key Joint Laboratory for Environmental Simulation \& Pollution Control, College of Environmental Science and Engineering, Peking \\ University, Beijing 100871, China; \\ ${ }^{2}$ National Marine Environmental Monitoring Centre, Dalian 116023, China
}

Received September 15, 2011; accepted November 21, 2011; pubished online February 15, 2012

\begin{abstract}
Dioxin-like polychlorinated biphenyls (PCBs) are a class of toxic and persistent chemicals that are often found in the environment. The determination of dioxin-like PCBs in Fildes Peninsula, Antarctica, is reported in this paper. Dioxin-like PCBs were widely distributed in Antarctic soil and moss with concentration of 2.23-27.2 pg/g in soil and 10.4-812 pg/g in moss. The highest concentrations were found in the Ardley Island area and the lowest concentrations on the west coast. The contribution of PCB-118 to the $\sum_{12} \mathrm{PCBs}$ ranged from $36.0 \%$ to $69.6 \%$ in soil, and $17.2 \%$ to $43.4 \%$ in moss. The congener specific patterns in soil and moss were similar. Long-range atmospheric transport is thought to be the main source of PCBs detected on King George Island. The $\sum_{12} \mathrm{PCBs}$ toxic equivalent (TEQ) in soil was $0.400 \times 10^{-3}$ to $516 \times 10^{-3} \mathrm{pg}$ (TEQ) $/ \mathrm{g}$ with a mean value of $147 \times 10^{-3} \mathrm{pg}(\mathrm{TEQ}) / \mathrm{g}$. PCB-126 had the largest contribution (81.1\%) to the $\sum_{12} \mathrm{PCBs}$ TEQ in soil. The $\sum_{12} \mathrm{PCBs}$ TEQ in moss ranged from $2.90 \times 10^{-3}$ to $1.19 \mathrm{pg} / \mathrm{g}$ with a mean value of $0.482 \mathrm{pg} / \mathrm{g}$. PCB-126 was also the largest contributor (91.4\%) to the $\sum_{12} \mathrm{PCBs}$ TEQ in moss. The mean TEQ in moss was about 40 times that in soil.
\end{abstract}

Fildes Peninsula, dioxin-like PCBs, concentration, congener distribution

Citation: Wang Q, Shi Y H, Hu J X, et al. Determination of dioxin-like polychlorinated biphenyls in soil and moss from Fildes Peninsula, Antarctica. Chin Sci Bull, 2012, 57: 992-996, doi: 10.1007/s11434-011-4969-y

Dioxins are a class of structurally and chemically related halogenated aromatic hydrocarbons. Polychlorinated dibenzodioxins (PCDDs or dioxins), polychlorinated dibenzofurans (PCDFs or furans) and the dioxin-like polychlorinated biphenyls (PCBs) are all dioxins that share similar chemistry and are toxic and persistent in the environment $[1,2]$. The main sources of dioxin-like polychlorinated biphenyls (dioxin-like PCBs) such as PCB-81, PCB-77, PCB-105, PCB-114, PCB-118, PCB-123, PCB-126, PCB-156, PCB-157, PCB-167, PCB-169, PCB-189, are commercial products that are used in industrial capacitors and transformers, and oil painting. Dioxins have been detected in a wide range of agricultural and environmental soils and sediments [3-6].

Soils play an important role in the global cycling of persistent organic pollutants (POPs). They store POPs from

*Corresponding author (email: jianxin@pku.edu.cn) atmospheric deposition and direct pollution through transformation of the soil organic matter content and type. A series of articles have reported the role of background soils in global POP budgets, air-surface soil exchange, and the influence of soil organic matter on these processes [7-9]. Vegetation is the primary site for bioaccumulation of POPs, which occurs by uptake of lipophilic organic compounds from the air into plant tissues. Soil pollutants can also be taken up by vegetation since both soil and vegetation have a high affinity for hydrophobic organic pollutants and can act as natural sinks [10]. The Polar region is very vulnerable to human activity and POPs, and it is very important to evaluate the risk of contamination of this environment with dioxinlike PCBs and their distribution [11].

While some studies have reported the presence of POPs in the Antarctic region is the result of long-range atmospheric transport $[12,13]$, several other studies have reported that 
the pollution comes from local sources around research stations $[10,14,15]$. There are many reports on the total PCB levels in Antarctic soil, seawater, and sediment [16-18], but information on dioxin-like PCBs in this region is very limited.

In this study, the concentrations of 12 dioxin-like PCB congeners in soil and moss were measured along the Fildes Peninsula, Antarctica. This data will aid understanding of the contribution of this area to the global POP cycle.

\section{Materials and methods}

\subsection{Sampling and sample preparation}

The Great Wall Station $\left(62^{\circ} 13^{\prime} \mathrm{S}, 58^{\circ} 59^{\prime} \mathrm{W}\right)$ is located on the Fildes Peninsula, King George Island, Antarctica. This area is affected by polar cyclones and has a cold subantarctic climate, which is dominated by west and northwest winds. The average annual temperature is $-1.5^{\circ} \mathrm{C}$ with a maximum temperature of $8.5^{\circ} \mathrm{C}$ and lowest temperature of $-20.3^{\circ} \mathrm{C}$. The average annual wind speed, pressure and relative humidity are $7.1 \mathrm{~m} / \mathrm{s}, 9.91 \times 10^{4} \mathrm{~Pa}$, and $86 \%$, respectively. The annual rainfall in this area is about $630 \mathrm{~mm}$, and mainly in the form of snow. The depth of freeze-thaw soil reaches a maximum of 40-70 $\mathrm{cm}$ in late March [19] after increasing from mid-December when surface snow and soil begin to melt. Most of the ice free area is covered by abundant vegetation, which is dominated by cryptogamic species, including two flowering plants, 33 bryophytes, and 62 lichens [19]. The thickness of fine particles and organic clay soil under the lichen moss layer is about $10-15 \mathrm{~cm}$. This kind of soil comes from freezing, thawing, and the root soil's biogeochemical process [20].

Surface soil samples (upper $5 \mathrm{~cm}$ ) and moss samples were collected on Fildes Peninsula, King George Island from December 2007 to January of 2008. As illustrated in Figure 1 and Table 1, 15 sampling sites, S1-S15, were selected on Fildes Peninsula. The average temperature during sampling was $2.5^{\circ} \mathrm{C}$. All samples were wrapped in aluminum foil and stored at $-20^{\circ} \mathrm{C}$. Soil and moss samples were freeze-dried, ground, and sieved (80 mesh) before accelerated solvent extraction (ASE-300, Dionex, Sunnyvale, CA, USA) at $185^{\circ} \mathrm{C}$ and $10.3 \mathrm{MPa}$. About $20.0 \mathrm{~g}$ of a homogenized soil or moss sample was statically extracted using toluene in a $33 \mathrm{~mL}$ cell. After cleanup by multi-layer silica gel (pesticide grade, Merck KGaA, Darmstadt, Germany), a basic alumina column (Brockmann I, standard grade, Aldrich Chemical Co., Milwaukee, USA), and gel permeation chromatography (Bio-Beads SX3, Bio-Rad, Hercules, CA, USA), the soil and moss samples were fractionated on a Florisil column (60100 mesh, Riedel de Haen, Seelze, Germany). The desired fraction was concentrated on a rotary evaporator and analyzed on a high-resolution gas chromatography high-resolution mass spectrometer (JMS 700D, JEOL, Tokyo, Japan) equipped with a J\&W Scientific DB-5MS column $(60 \mathrm{~m} \times 0.25 \mathrm{~mm}$ I.D., $0.25 \mu \mathrm{m}$ particle size, Agilent, Santa Clara, CA, USA) in selected ion monitoring mode.

\subsection{Reagents}

Standard solutions of dioxin-like PCBs, including PCB-

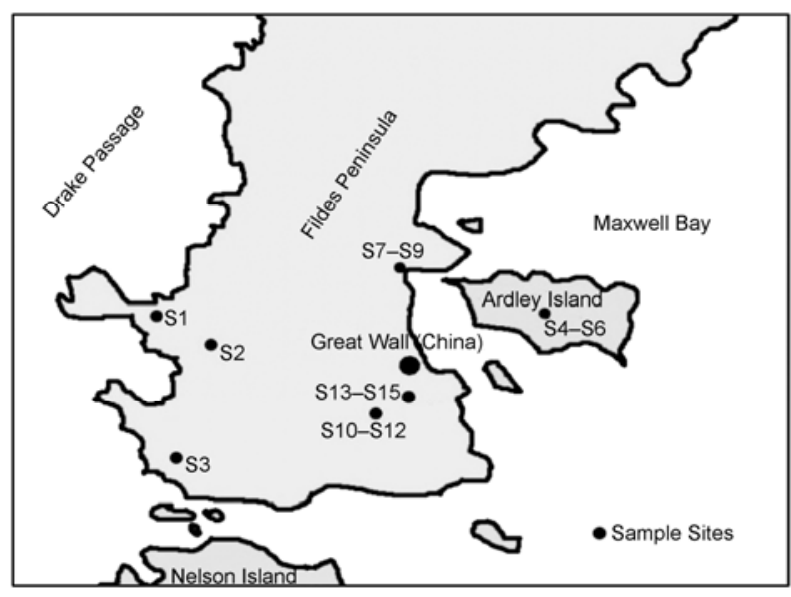

Figure 1 The study area and locations of the sampling sites.

Table 1 Description of the samples and sampling locations

\begin{tabular}{|c|c|c|c|c|c|}
\hline Serial number & Sites & Sampling time & \multicolumn{2}{|c|}{ Sampling location (GPS) } & Description \\
\hline S1 & West Coast & $2007-12-26$ & $\mathrm{~S} 62^{\circ} 12^{\prime} 56.6^{\prime \prime}$ & W58 $59^{\prime} 35.0^{\prime \prime}$ & Dark brown soil. Lichen and moss are abundant. \\
\hline $\mathrm{S} 2$ & & & $\mathrm{~S} 62^{\circ} 12^{\prime} 40.0^{\prime \prime}$ & W59 $09^{\circ} 29.2^{\prime \prime}$ & Light brown soil. Fruticose lichens are dominant. \\
\hline $\mathrm{S} 3$ & & & $\mathrm{~S} 62^{\circ} 13^{\prime} 36.5^{\prime \prime}$ & $\mathrm{W} 59^{\circ} 00^{\prime} 03.1^{\prime \prime}$ & Dark brown soil. Lichen and moss are abundant. \\
\hline S4-S6 & Ardley Island & $2008-1-4$ & $\mathrm{~S} 62^{\circ} 12^{\prime} 44.9^{\prime \prime}$ & W58 $55^{\prime} 34.3^{\prime \prime}$ & $\begin{array}{l}\text { Dark brown soil. Moss is dominant (wet condition). } \\
\text { Frequented by seabirds and penguin. }\end{array}$ \\
\hline S7-S9 & Mountain Lakes & $2008-1-11$ & $\mathrm{~S} 62^{\circ} 12^{\prime} 32.5^{\prime \prime}$ & W58 $57^{\prime} 15.2^{\prime \prime}$ & $\begin{array}{l}\text { Light reddish brown soil in slope. Soil sample was } \\
\text { collected from the newly exposed surface. } \\
\text { Sea-birds feathers and droppings are common (near the } \\
\text { penguin rookery). }\end{array}$ \\
\hline S10-S12 & Tern Lake & $2008-1-13$ & $\mathrm{~S} 62^{\circ} 13^{\prime} 15.0^{\prime \prime}$ & W58 $57^{\prime} 33.2^{\prime \prime}$ & Light brown soil. Fruticose lichens are dominant. \\
\hline S13-S15 & Great Wall Station area & $2008-1-14$ & $\mathrm{~S} 62^{\circ} 13^{\prime} 08.3^{\prime \prime}$ & W58 $57^{\prime} 15.5^{\prime \prime}$ & Light brown soil in slope. Fruticose lichens are dominant. \\
\hline
\end{tabular}


CVS-JQ (calibration and verification solutions CS1-CS5), MBP-MXS (labeled compound stock solution) and MBP-79 (internal standard spiking solution), were purchased from the Wellington Laboratories (Ontario, Canada). Toluene, hexane, methylene chloride and acetone (pesticide grade) were purchased from Thermo Fisher Scientific (Waltham, MA, USA). Decane (dioxin level) was obtained from Wako Pure Chemical Industries, Ltd. (Osaka, Japan).

\subsection{Instrumental analysis}

For GC the carrier gas flow rate was $1.5 \mathrm{~mL} / \mathrm{min}$, and the injection volume was $1 \mu \mathrm{L}$. The column temperature was programmed as follows: held at $150^{\circ} \mathrm{C}$ for $1 \mathrm{~min}$, heated to $185^{\circ} \mathrm{C}$ at $20^{\circ} \mathrm{C} / \mathrm{min}$, maintained at this temperature for $3 \mathrm{~min}$, heated to $245^{\circ} \mathrm{C}$ at $2^{\circ} \mathrm{C} / \mathrm{min}$, maintained at this temperature for $3 \mathrm{~min}$, and finally heated to $280^{\circ} \mathrm{C}$ at $6^{\circ} \mathrm{C} / \mathrm{min}$ and held for $5 \mathrm{~min}$. The injector temperature was $280^{\circ} \mathrm{C}$. MS was performed under the following conditions: vacuum, $<1 \times 10^{-3} \mathrm{~Pa}$; ionization energy, $38 \mathrm{eV}$; ion current, $500 \mu \mathrm{A}$; electron ionization source temperature, $280^{\circ} \mathrm{C}$; accelerating voltage, $10 \mathrm{kV}$; and resolution, $>10000$. Mass calibration was performed with perfluorokerosene (PFK). The spectra were processed with JEOL Diok V4.02 software (Tokyo, Japan). The total organic carbon (TOC) of the soil was determined using the potassium dichromate method [21].

\subsection{Quality assurance and quality control}

The stainless steel shovels used for sampling were cleaned with solvent before use. The aluminum foil used to wrap samples was heated at $450^{\circ} \mathrm{C}$ for $4 \mathrm{~h}$ before being placed in a dense vinyl bag and stored at $-20^{\circ} \mathrm{C}$. Field blank samples were treated in the same way. One procedural blank sample was analyzed for every five soil extracts. All results were blank corrected. The limit of detection (LOD) was calculated as three times the standard deviation of the mean of the blank. The LODs of the congeners ranged from 0.0100 to $0.0630 \mathrm{pg} / \mathrm{g}$. Concentrations of samples that were below the LOD were replaced by a value of half the LOD. All samples were spiked with a labeled recovery standard. The recoveries ranged from $35.0 \%$ to $115 \%$ (average $89.0 \%$ ). These recoveries are in line with US EPA 1668 requirements [22].

\section{Results and discussion}

\subsection{Dioxin-like PCB levels}

Although there are many reports on PCBs in soils around the world, information on the dioxin-like PCB composition of Antarctic soil is scarce. Concentrations of dioxin-like PCBs in the soil and moss on Fildes Peninsula are displayed in Table 2. Dioxin-like PCBs were detected in all the samples. The summed concentration of all 12 dioxin-like PCBs congeners $\left(\sum_{12} \mathrm{PCBs}\right)$ in soil ranged from $2.23-27.2 \mathrm{pg} / \mathrm{g}$ (average $13.2 \mathrm{pg} / \mathrm{g}$ ). The highest $\sum_{12} \mathrm{PCBs}$ was observed in the Ardley Island area (S4-S6) and the lowest on the west coast (S1). The PCB concentrations in surface soils from Fildes Peninsula (2.23-27.2 pg/g) were much lower than those in soils from Zhejiang $\left(1.52 \times 10^{3}\right.$ to $\left.318 \times 10^{3} \mathrm{pg} / \mathrm{g}\right)$ [23] and Beijing, China $\left(0.390 \times 10^{3}\right.$ to $\left.13.0 \times 10^{3} \mathrm{pg} / \mathrm{g}\right)$ [24], but higher than those from Barton Peninsula, Antarctica (0.893$2.30 \mathrm{pg} / \mathrm{g})$. The $\sum_{12} \mathrm{PCBs}$ concentration in moss ranged from $10.4-812 \mathrm{pg} / \mathrm{g}$, with a mean concentration of $385 \mathrm{pg} / \mathrm{g}$, which was about 29 times that of the soil concentration.

$\sum_{12} \mathrm{PCBs}$ in soil from the Ardley Island area and the Greatwall Station area were much higher than those in soil

Table 2 Concentrations of dioxin-like PCB congeners (pg/g) and TEQ (pg(TEQ)/g) in soil and moss samples collected from Fildes Peninsula ${ }^{\text {a) }}$

\begin{tabular}{|c|c|c|c|c|c|c|c|c|c|c|c|c|c|c|c|}
\hline \multirow{2}{*}{ Congener } & \multicolumn{7}{|c|}{ Soil (pg/g) } & \multicolumn{7}{|c|}{ Moss (pg/g) } & \multirow{2}{*}{$\begin{array}{c}\begin{array}{c}\mathrm{Air}^{[25]} \\
\left(\mathrm{fg} / \mathrm{m}^{3}\right)\end{array} \\
\mathrm{F}\end{array}$} \\
\hline & $\mathrm{S} 1$ & $\mathrm{~S} 2$ & $\mathrm{~S} 3$ & S4-S6 & S7-S9 & S10-S12 & S13-S15 & $\mathrm{S} 1$ & $\mathrm{~S} 2$ & S3 & S4-S6 & S7-S9 & S10-S12 & S13-S15 & \\
\hline PCB-77 & 0.280 & 0.520 & 0.570 & 3.69 & 3.35 & 0.300 & 1.17 & 0.00 & 10.9 & 0.560 & 43.2 & ND & 5.89 & ND & 40.0 \\
\hline PCB-81 & ND & ND & ND & ND & ND & ND & 0.12 & ND & ND & ND & ND & ND & ND & ND & ND \\
\hline PCB-105 & 0.220 & 0.240 & 0.790 & 4.76 & 4.32 & 0.720 & 3.30 & 82.8 & 7.42 & 1.89 & 137 & 99.8 & 7.14 & 130 & 50.0 \\
\hline PCB-114 & ND & 0.0200 & ND & ND & ND & ND & ND & 1.32 & ND & ND & 4.09 & 10.4 & ND & 13.5 & ND \\
\hline PCB-118 & 0.800 & 0.950 & 2.73 & 14.3 & 13.0 & 2.34 & 13.7 & 194 & 25.5 & 5.70 & 393 & 375 & 20.4 & 488 & 180 \\
\hline PCB-123 & 0.0200 & 0.140 & ND & 2.05 & 1.87 & ND & 2.49 & 19.5 & 1.70 & 0.600 & 54.2 & 23.1 & 2.10 & 30.0 & ND \\
\hline PCB-126 & 0.120 & 0.270 & ND & ND & ND & ND & 0.450 & 6.78 & 3.64 & 0.160 & 9.39 & 8.14 & 1.43 & 10.6 & ND \\
\hline PCB-156 & 0.120 & 0.100 & ND & 1.44 & 1.31 & ND & 3.07 & 37.7 & 4.57 & 0.680 & 63.0 & 50.1 & 1.99 & 65.1 & 10.0 \\
\hline PCB-157 & 0.150 & 0.0700 & ND & 0.0200 & 0.0200 & ND & 0.550 & 11.4 & 1.79 & 0.240 & 18.4 & 15.1 & 1.08 & 19.7 & 60.0 \\
\hline PCB-167 & 0.200 & 0.110 & ND & 1.36 & 1.24 & ND & 1.52 & 17.9 & 3.20 & 0.440 & 46.9 & 38.8 & 1.30 & 50.4 & 20.0 \\
\hline PCB-169 & 0.320 & 0.170 & ND & ND & ND & ND & 0.310 & ND & ND & ND & ND & ND & ND & ND & 10.0 \\
\hline PCB-189 & ND & ND & ND & ND & ND & ND & 0.520 & ND & 0.690 & 0.0700 & 5.94 & 3.67 & ND & 4.77 & ND \\
\hline$\sum_{12} \mathrm{PCBs}$ & 2.23 & 2.59 & 4.09 & 27.7 & 25.1 & 3.36 & 27.2 & 372 & 59.4 & 10.4 & 775 & 624 & 41.3 & 812 & 370 \\
\hline $\operatorname{TEQ}\left(\times 10^{-3}\right)$ & 158 & 28.5 & 0.400 & 3.20 & 2.90 & 0.300 & 51.6 & 733 & 372 & 17.0 & 1050 & 902 & 148 & 1170 & 162 \\
\hline $\begin{array}{l}\text { TOC } \\
\text { (g/kg dry weight) }\end{array}$ & 25.7 & 28.4 & 30.1 & 65.4 & 60.8 & 15.5 & 45.4 & - & - & - & - & - & - & - & - \\
\hline
\end{tabular}

a) ND: not detected. 
samples from other sites in this study. Similar results were found for $\sum_{12} \mathrm{PCBs}$ in moss. These higher concentrations might be caused by local contamination because of human activity at the research stations in these areas and animal activity. Choi et al. [25] reported that PCB levels in atmospheric samples decreased with increasing distance from the main building of King Sejong Station, Barton Penisula, Antarctica. Hyun et al. [10] found that soil samples collected near the research station had elevated concentrations of chlorinated homologues compared to other samples, which implies that local pollution influences the concentrations in this area. Many studies have suggested that animal activity and TOC can have a large cumulative effect on the distribution of POPs [26-28]. The dry weight TOC contents in soil samples from sites S1-S15 are shown in Figure 2. The TOC values ranged from $15.5-65.4 \mathrm{~g} / \mathrm{kg}$. Correlation analysis showed a high correlation coefficient between $\sum_{12} \mathrm{PCBs}$ and TOC content in soil samples $\left(r^{2}=0.828, P \leqslant 0.05\right)$. Ardley Island is a habitat for birds and other animals, and is covered with moss. This means the soil is ornithogenic and rich in organic carbon. As a result, bioaccumulation of PCBs may lead to heavy contamination on a local scale.

The toxic equivalents (TEQs) of dioxin-like PCBs at the different sampling sites (Table 2) were calculated according to the World Health Organization toxic equivalency factors (WHO-TEF) [29]. The $\sum_{12} \mathrm{PCBs}$ TEQs in soil ranged from $0.400 \times 10^{-3}$ to $51.6 \times 10^{-3} \mathrm{pg}$ (TEQ)/g (mean $147 \times 10^{-3} \mathrm{pg}$ (TEQ)/g). PCB-126 accounted for $81.1 \%$ of the $\sum_{12} \mathrm{PCBs}$ TEQ, and the other major contributors were PCB-169 (7.77\%), PCB-118 (approximately 4.65\%) and PCB-156 (approximately $2.94 \%$ ). The $\sum_{12} \mathrm{PCBs}$ TEQs in moss ranged from $17.0 \times 10^{-3}$ to $1.17 \mathrm{pg}$ (TEQ)/g (mean $0.627 \mathrm{pg} / \mathrm{g}$ ). PCB126 was again the largest contributor $(91.4 \%)$ to the $\sum_{12} \mathrm{PCBs}$ TEQs in moss, followed by PCB-118 (approximately $3.42 \%$ ), PCB-156 (approximately 2.54\%) and PCB-105 (approximately $1.05 \%$ ). The mean TEQ value for moss was about 40 times that of the soil.

\subsection{Congener patterns in soil and moss samples}

The percentage contribution of each of the 12 dioxin-like

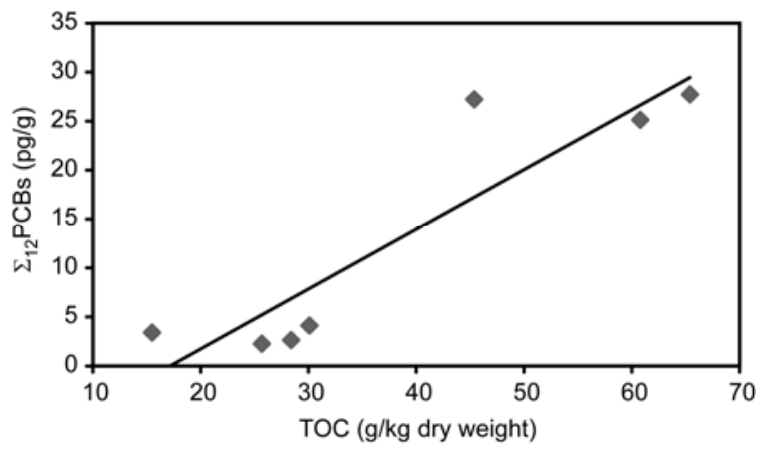

Figure 2 Correlation of $\sum_{12} \mathrm{PCBs}$ and TOC in soil samples.
PCBs to the $\sum_{12} \mathrm{PCBs}$ in soil and moss are presented in Figure 3 . The congener specific patterns were similar in the soil and moss samples. The most abundant congeners in these samples were PCB-118, PCB-105, and PCB-77. These congeners accounted for $51.9 \%$ (PCB-118), 15.6\% (PCB$105)$ and $10.7 \%$ (PCB-77) of the $\sum_{12} \mathrm{PCBs}$ in soil and $38.4 \%$ (PCB-118), $11.9 \%$ (PCB-105), 5.70\% (PCB-77) of the $\sum_{12} \mathrm{PCBs}$ in moss. Among the 12 congeners, PCB-118 was predominant in both soil and moss samples. The contributions of PCB-118 to the $\sum_{12} \mathrm{PCBs}$ at the different sample sites ranged from $36.0 \%-69.6 \%$ in soil, and $17.2 \%-$ $43.4 \%$ in moss.

Pearson correlation of the 12 congeners among the soil and moss samples was examined (Table 3). Significant correlations were observed among all the sites, which implies that the sources of dioxin-like PCBs in soil and moss are the same. The large proportion of PCB compounds found in Antarctica could be attributed to atmospheric transport and deposition. Hyun et al. [10] reported the distribution of dioxinlike PCB in soil and lichen on Barton Peninsula, King George Island. It is interesting to note that the dioxin-like PCB congeners found in the Barton Peninsula soil samples have a good correlation with those found in the Fildes Peninsula. This suggests that the dioxin-like PCBs distributed in Greatwall Station area and the Korean Station area likely come from same source. Further comparison of the PCB congener concentrations in air samples from Fildes Peninsula and Barton Peninsula [25] showed a strong correlation. This suggests that long-range atmospheric transport may be the main source of dioxin-like PCBs in the study area.

\section{Conclusions}

Dioxin-like PCBs was found in all the Antarctic soil and moss samples examined in this study. The concentrations of $\sum_{12} \mathrm{PCBs}$ ranged from 2.23 to $27.7 \mathrm{pg} / \mathrm{g}$ in soil and 10.4 to $812 \mathrm{pg} / \mathrm{g}$ in moss. The highest concentration of $\sum_{12} \mathrm{PCBs}$

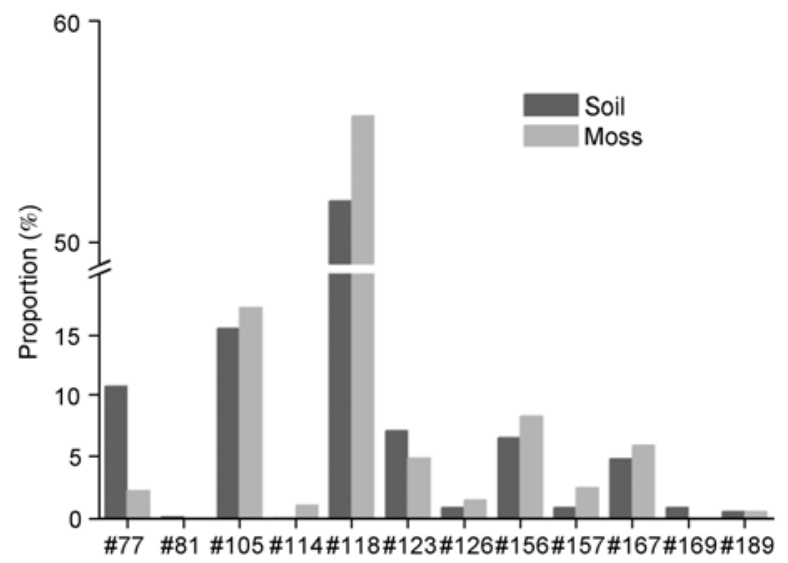

Figure 3 Percent contribution of each individual congener to $\sum_{12} \mathrm{PCBs}$ in soil and moss samples. 
Table 3 Pearson correlation coefficients of the dioxin-like congeners among the different samples ${ }^{\text {a) }}$

\begin{tabular}{|c|c|c|c|c|c|c|c|}
\hline & $\mathrm{S} 1$ & $\mathrm{~S} 2$ & S3 & S4-S6 & S7-S9 & S10-S12 & S13-S15 \\
\hline Moss-soil & $0.831^{*}$ & $0.962^{* *}$ & $0.979^{* * *}$ & $0.984^{* * *}$ & $0.958^{* * *}$ & $0.984^{* *}$ & $0.986^{* *}$ \\
\hline Soil $^{* * *}$-soil & $0.881^{* *}$ & $0.873^{* * *}$ & $0.934^{* *}$ & $0.936^{* *}$ & $0.936^{* *}$ & $0.922^{* *}$ & $0.841^{*}$ \\
\hline $\mathrm{Air}^{* * * *}$-soil & $0.908^{* * *}$ & $0.858^{* *}$ & $0.944^{* *}$ & $0.923^{* *}$ & $0.923^{* *}$ & $0.942^{* *}$ & $0.903^{* *}$ \\
\hline $\operatorname{Air}^{\text {**** }}-$ moss & $0.903^{* *}$ & $0.917^{* *}$ & $0.934^{* *}$ & $0.925^{* *}$ & $0.923^{* *}$ & $0.938^{* *}$ & $0.923^{* *}$ \\
\hline
\end{tabular}

a) $* P<0.05 ; * * P<0.01 ; * * *$ Choi et al. [25].

was observed in the Ardley Island area. Bioaccumulation and biologically mediated transport of PCBs could increase contamination on a local scale.

The contribution of PCB-118 to $\sum_{12} \mathrm{PCB}$ ranged from $36.0 \%$ to $69.6 \%$ in soil, and $17.2 \%$ to $43.4 \%$ in moss. The congener specific patterns in soil and moss were similar, which suggests that the dioxin-like PCBs in soil and moss come from the same source.

This work was supported by the Postdoctoral Science Foundation of China (201004800123), the China Polar Science Strategic Fund (20070214), and the Foundation of State Key Joint Laboratory for Environmental Simulation \& Pollution Control.

1 Davy C W. Legislation with respect to dioxins in the workplace. Environ Int, 2004, 30: 219-233

2 Srogi K. Levels and congener distributions of PCDDs, PCDFs and dioxin-like PCBs in environmental and human samples: A review. Environ Chem Lett, 2008, 6: 1-28

3 Liu J S, Liu W P. Distribution of polychlorinated dibenzo-p-dioxins and dibenzofurans (PCDDs/Fs) and dioxin-like polychlorinated biphenyls (dioxin-like PCBs) in the soil in a typical area of eastern China. J Hazard Mater, 2009, 163: 959-966

4 Cai Q Y, Mo C H, Wu Q T, et al. The status of soil contamination by semivolatile organic chemicals (SVOCs) in China: A review. Sci Total Environ, 2008, 389: 209-224

5 Zheng $\mathrm{M} \mathrm{H}$, Chu S G, Sheng G Y, et al. Polychlorinated dibenzo$p$-dioxins and dibenzofurans in surface sediments from Pearl River Delta in China. Bull Environ Contam Toxicol, 2001, 66: 504

6 Zhao X, Zheng M, Zhang B, et al. Evidence for the transfer of polychlorinated biphenyls, polychlorinated dibenzo- $p$-dioxins, and polychlorinated dibenzofurans from soil into biota. Sci Total Environ, 2006, 368: 744-752

7 Nam J J, Gustafsson O, Perihan K K, et al. Relationships between organic matter, black carbon and persistent organic pollutants in European background soils: Implications for sources and environmental fate. Environ Pollut, 2008, 156: 809-817

8 Meijer S N, Ockenden W A, Sweetman A J, et al. Global distribution and budget of PCBs and HCB in background surface soils: Implications for sources and environmental processes. Environ Sci Technol, 2003, 37: 667-672

9 Hassanin A, Lee R G M, Steinnes E, et al. PCDD/Fs in Norwegian and U.K. soils: Implications for sources and environmental cycling. Environ Sci Technol, 2005, 39: 4784-4792

10 Hyun P, Lee S H, Kim M, et al. Polychlorinated biphenyl congeners in soils and lichens from King George Island, South Shetland Islands, Antarctica. Antarct Sci, 2010, 22: 31-38

11 Olav O. Protecting the environment of the Arctic ecosystem. Panel on "Protecting Vulnerable marine ecosystems"-_United Nations Openended Informal Consultative Process on Oceans and the Law of the
Sea. Fourth Meeting, 2003

12 Wania F, Mackay D. Global fractionation and cold condensation of low volatility organochlorine compounds in polar regions. Ambio, 1993, 22: 10-18

13 Loganathan B G, Kannan K. Global organochlorine contamination trends: An overview. Ambio, 1994, 23: 187-191

14 Risebrough R W, Delappe B W, Younghans H C. PCB and PCT contamination in Winter Quarters Bay, Antarctica. Mar Pollut Bull, 1990, 21: 523-529

15 Larsson P, Jarnmark C, Sodergren A. PCBs and chlorinated pesticides in the atmosphere and aquatic organisms of Ross Island, Antarctica. Mar Pollut Bull, 1992, 25: 281-287

16 Montone R C, Taniguchi S, WEBER R R. Polychlorinated biphenyls in marine sediments of Admiralty Bay, King George Island, Antarctica. Mar Pollut Bull, 2001, 42: 611-614

17 Negoita T G, Covaci A, Gheorghe A, et al. Distribution of polychlorinated biphenyls (PCBs) and organochlorine pesticides in soils from the East Antarctic coast. J Environm Monit, 2003, 5: 281-286

18 Klanova J, Matykiewiczova N, Macka Z, et al. Persistent organic pollutants in soils and sediments from James Ross Island, Antarctica. Environ Pollut, 2008, 152: 416-423

19 Yang Q H, Wang X Q, Zhang L. The features of the meteorological elements in 2006 at the Great Wall Station, Antarctica (in Chinese). Mar Forecast, 2007, 4: 55-64

20 Sun L G, Xie Z Q, Zhao J L, et al. Monitoring the concentration of $\mathrm{N}_{2} \mathrm{O}$ in the Fildes Peninsula, maritime Antarctica. Chin Sci Bull, 2000, 45: 2000-2004

21 Bao S D. Soil Analysis in Agricultural Chemistry (in Chinese). Beijing: Chinese Agriculture Press, 2000. 56-58

22 US EPA. Method 1668 Revision A: Chlorinated Biphenyl Congeners in Water, Soil, Sediment, and Tissue by HRGC/HRMS. Washington: US Environmental Protection Agency, 1999. 133

23 Han J L, Shen H T, Yu C, et al. Primary investigation of PCDD /Fs and PCBs in soils from some areas in Zhejiang (in Chinese). Chinese J Health Lab Technol, 2009, 5: 1124-1127

24 Liu G Y, Chen Z S, Shi Y H, et al. The levels and compositions of PCBs in Beijing soil (in Chinese). Acta Scientiae Circum Stantiae, 2006, 26: 2013-2017

25 Choi S D, Baek S Y, Chang Y S, et al. Passive air sampling of polychlorinated biphenyls and organochlorine pesticides at the Korean Arctic and Antarctic research stations: Implications for long-range transport and local pollution. Environ Sci Technol, 2008, 42: 7125-7131

26 Negoita T G, Covaci A, Gheorghe A, et al. Distribution of polychlorinated biphenyls (PCBs) and organochlorine pesticides in soils from the East Antarctic coast. J Environ Monit, 2003, 5: 281-286

27 Goerke H, Weber K, Bornemann H, et al. Increasing levels and biomagnification of persistent organic pollutants (POPs) in Antarctic biota. Mar Pollut Bull, 2004, 48: 295-302

28 Yogui G T, Sericano J L. Polybrominated diphenyl ether flame retardants in lichens and mosses from King George Island, maritime Antarctica. Chemosphere, 2008, 73: 1589-1593

29 Vandenberg M, Birnbaum L, Bosveld A T C, et al. Toxic equivalency factors (TEFs) for PCBs, PCDDs, PCDFs for humans and wildlife. Environ Health Perspect, 1998, 106: 775-792

Open Access This article is distributed under the terms of the Creative Commons Attribution License which permits any use, distribution, and reproduction in any medium, provided the original author(s) and source are credited. 